\title{
Decentralized control of human visceral leishmaniasis in endemic urban areas of Brazil: a literature review
}

\author{
Sonia S. Menon ${ }^{1,2^{*}}$, Rodolfo Rossi ${ }^{3}$, Leon Nshimyumukiza ${ }^{4}$ and Kate Zinszer $^{5}$
}

\begin{abstract}
Objectives: Human migration and concomitant HIV infections are likely to bring about major changes in the epidemiology of some parasitic infections in Brazil. Human visceral leishmaniasis (HVL) control is particularly fraught with intricacies. It is against a backdrop of decentralized health care that the complex HVL control initiatives are brought to bear. This comprehensive review aims to explore the obstacles facing decentralized HVL control in urban endemic areas in Brazil.

Method: A literature search was carried out in December 2015 by means of three databases: MEDLINE, Google Scholar, and Web of Science.

Results: Although there have been many strides that have been made in elucidating the eco-epidemiology of Leishmania infantum, which forms the underpinnings of the national control program, transmission risk factors for HVL are still insufficiently elucidated in urban settings. Decentralized HVL epidemiological surveillance and control for animal reservoirs and vectors may compromise sustainability. In addition, it may hamper timely human HVL case management. With the burgeoning of the HIV-HVL co-infection, the potential human transmission may be underestimated.

Conclusion: HVL is a disease with focal transmission at a critical juncture, which warrants that the bottlenecks facing the control program within contexts of decentralized healthcare systems be taken into account. In addition, HIV-driven HVL epidemics may substantially increase the transmission potential of the human reservoir. Calculating the basic reproductive number to fine-tune interventions will have to take into consideration the specific socio-economic development context.
\end{abstract}

Keywords: Human visceral leishmaniasis, HIV, Control and prevention, Decentralization, Human reservoir, Basic reproductive number, Visceral leishmaniasis, HIV co-infection

\section{Background}

Human visceral leishmaniasis (HVL) is endemic in 70 countries [1]. Leishmania infantum chagasi is the main species causing HVL in Brazil. It is transmitted by sandflies, the species Lutzomyia longipalpis being the most important HVL vector in the New World. The parasite L. infantum multiplies within the sandfly for a period between 8 and 20 days and, in humans, it has an

\footnotetext{
* Correspondence: soniasimonemenon@gmail.com

${ }^{1}$ International Centre for Reproductive Health (ICRH), Ghent University, De

Pintelaan 185 P3, 9000 Ghent, Belgium

'Department of Epidemiology and Biostatistics, McGill University, Montreal,

Canada

Full list of author information is available at the end of the article
}

incubation period of between 2 and 6 months [2]. In Brazil, canines are the main reservoirs [3], with humans not considered necessary for maintaining transmission within the community. A recent mathematical model demonstrated that the insecticide-impregnated dog collars and vector control [4] were the most effective interventions in reducing the prevalence of HVL in humans.

The HVL disease burden in Latin America is unknown as most countries lack effective surveillance systems, resulting in substantial underreporting [5-7], Brazil, which harbors $90 \%$ of the VL cases documented on the American continent, [8] registered 70 thousand cases of 
HVL between 1980 and 2008 resulted in the deaths of more than 3800 people $[9,10]$.

The typical manifestations of HVL include fever, weight loss, hepatosplenomegaly, and pancytopenia resulting from replication of Leishmania amastigotes in macrophages mainly in the liver, spleen, and bone marrow, causing severe and ultimately lethal lesions [11]. Typical features such as splenomegaly may be absent in VL-HIV-co-infected patients [12], whereas atypical organ involvement, such as of the lungs or gastrointestinal system and renal failure has been associated with chronic VL in HIV patients [13-15]. Conversely, as HIV viral load increases in patients with HIV-Leishmania co-infection [16], it promotes the clinical progression of HIV and the development of AIDSdefining conditions [17].

HVL was formerly restricted to rural areas in Brazil, but since the 1980s, it has been spreading to urban centers. This spread has also lead to increasing numbers of HIV co-infected cases [18], as HIV is also endemic in urban centers in Brazil [19]. In 1988, Brazil adopted a new federal constitution that called for a nationally unified health system and facilitated the process of municipalization. In this process, municipal governments, the smallest autonomous political and geographic unit within the federal system, took on increasing levels of resources and responsibility for a range of health and other services, based in part on evaluations of their managerial capacities [20].

From the 1950s to the end of the 1990s, the Brazilian VL program was the responsibility of the federal government. As result of the decentralization of the control programs for epidemics, the control of leishmaniasis has become the responsibility of the municipality [21, 22]. The decentralization of the program to the states and municipalities has been implemented amidst difficulties at these levels of governments, which have insufficient accumulated experience in control [23]. Control programs over the past 20 years in Brazil have been accompanied by a substantial decentralization process [24], which has been attributed to the successful control of cholera, Chagas, and vaccine-preventable diseases [10] but unsuccessful for certain vector-borne diseases including HVL and dengue fever, both vector-borne diseases with changing epidemiological profiles [10].

The objectives of this review were to highlight the potential shortcomings of a HVL control program in a decentralized context and to identify the clinical and epidemiological research gaps for HVL control and prevention.

\section{Methods}

A literature search was carried out in December 2015 by means of three electronic databases: MEDLINE (1948-
December 2015), Google Scholar, and Web of Science (1899-December 2015). Papers in English and Portuguese were identified using medical subject headings and truncations

Control of the animal reservoir and arthropod vector: (visceral leishmaniasis OR Leishmania chagasi OR $L$ chagasi OR Kala-azar Leishmania infantum OR phlebotomine sandflies) AND "Brazil" AND control.

Diagnosis of human VL: (visceral leishmaniasis OR kala-azar OR L.infantum OR L. chagasi OR Leishmania infantum OR Leishmania chagasiA ND (diagnostic accuracy OR sensitivity OR specificity AND DAT OR dipstick) AND "Brazil"

Treatment of human VL: For the PubMed search the following key-words were used: (visceral leishmaniasis L. chagasi AND treatment OR amphotericin B OR Amphotericin B deoxycholate OR pentavalent antimonials OR) AND (HIV positive OR AIDS) AND "Brazil"

Diagnosis of canine VL: (canine visceral leishmaniasis OR L.infantum OR L.chagasi OR L.donovani OR Leishmania infantum OR Leishmania chagasi)AND (diagnostic accuracy OR diagnostic performance OR sensitivity OR specificity OR validation) AND "Brazil"

Decentralization of health care: (decentralization AND vector-borne diseases) AND Brazil OR (decentralization of health care AND Brazil)

An additional manual search was undertaken to include the bibliographies of the retrieved references.

\section{Results}

\section{Epidemiology}

Human visceral leishmaniasis (HVL) is a disease of public health importance caused by protozoans belonging to the genus Leishmania, which is present worldwide, particularly in Brazil, Bangladesh, India, Nepal, and Sudan [25]. The humans, animal reservoir, and vector share the same ecological niche, which contributes to the persistence of the disease. There is a consensus that the control of phlebotomine sandflies, the vector, is a daunting task as the identification of their breeding sites is challenging, which limits the effectiveness of control measures focused on immature forms of these vectors [26]. In Brazil, sandflies have spread in both rural and urban area, which contrasts with most other New World ecoepidemiological situations where sandflies are associated with forested areas.

Infectious dogs are considered the main reservoir and are estimated to have a basic reproduction number $\left(R_{0}\right)$ of 6 , meaning that each infected dog gives rise to an average of six new cases [27]. A study found that in the city of Petrolina (State of Pernambuco, northeast region, Brazil), of the 600 dogs tested, $19 \%$ presented anti- $L$. infantum antibodies [28]. The transmission of L. infantum, which was restricted to rural areas and spread in 
the 1980s to urban areas [9], is of great public health concern and is the result of the environmental changes, human disease reservoir migration, and adaptation of the sandflies vector to the peri-domiciliary [29]. In the last 20 years, despite the known underestimation of cases, Brazil registered a marked increase in the incidence of visceral leishmaniasis [27]. Whilst in the 1980s, HVL was considered a rural disease, HVL has spread throughout municipalities with $7 \%$ of municipalities being endemic in 1985; 18 \% in 1990; 30 \% in 1996 and, in 2014, endemicity was reported in 21 of the 26 Brazilian states plus the Federal District [30] and its control in urban areas constitutes a challenge [31]. In the 1980s, an average of 1500 cases was reported each year in Brazil, and between 2000 and 2009, the average increased to 3480 cases annually, an increase of $132 \%$ [32]. During the period of 2002-2009, case fatality rate varied between $8.5 \%$ in 2003 and $5.6 \%$ in 2008, with an average of $7.0 \%$, compared to $3.2 \%$ in 1994 [33]. However, case fatality rates derived from the national Database on Reportable diseases (SINAN) are subject to an underreporting of $45.5 \%$ [34] depending on the municipality, due to deficiencies in access to health services and quality of care along with atypical clinical manifestations [35].

Of the 44,289 cases reported in Brazil by SINAN during 1980 to 2000, $89.9 \%$ of these came from the northeast. Among all the Federal states in Brazil, Maranhão, a state in northeastern Brazil has recorded the highest number of cases of HVL. Between 2000 and 2009, 5389 cases of HLV were registered, with the highest incidence in the Regional health unit of Caxias, which reported 36.1 cases per 100,000 inhabitants [36].

In Northeastern Brazil, HIV has also become increasingly prevalent [37]; however, information on co-infection by VL and HIV in the northern region of Brazil is still scarce [38]. HIV-HVL co-infection has become an emerging public health issue [39]. The urbanization of HVL has resulted in a geographical overlap between HVL and AIDS in Brazilian inner cities [40].

\section{Diagnostics}

According to the Brazilian Ministry of Health, a diagnosis of HVL requires the identification of the parasite in a smear or culture and/or positive serological testing in patients presenting with fever and spleen enlargement [41]. The once widely used serological test for HVL diagnosis in Brazil immunofluorescence (IFI) [42], which was typically performed in referral laboratories around the country and required a delay of a few days to obtain the results [43], has been replaced by the use of rapid diagnostic tests (RDTs). This has been introduced to circumvent mortality by reducing diagnostic delay, as RDTs have been shown to improve the early detection of HVL, but their real-world performance in large urban settings requires additional study [34]. In Brazil, estimates of the sensitivity and specificity of RDTs vary between 85.7 and $100 \%$ and 82.0 and $100 \%$, respectively [44-47], although only a few studies have been conducted outside of controlled settings [48]. Additionally, RDTs have a low sensitivity for HVL among HIV-infected patients, estimated at $60 \%$ (95\% CI 40.7-76.6\%). This low sensitivity results in many undetected cases and therefore requires invasive parasite detection to diagnose atypically localized manifestations of VL [49]. The invasive nature of the tests, including the parasitological demonstration of the parasite in tissue smears requires considerable expertise [50] and carries the risk of potentially fatal bleeding. Due to high treatment failure and the relapsing nature of the disease, HIV-HVL patients are repeatedly exposed to these tests.

\section{Treatment}

The first drug for the treatment of leishmaniasis is pentavalent antimonial, which presents high toxicity and exhibits a recurrence rate of 20 to $45 \%$ [51-54]. The immune deficiency caused by HIV facilitates the multiplication of the Leishmania parasite and further reduces cure rates through conventional treatments [55-58]. In addition, HIV-HVL have higher rates of drug toxicity, higher mortality rates, resistance to pentavalent antimonial compounds, [59] and more relapses, especially if $\mathrm{CD} 4+$ counts are $<200$ cells $/ \mu \mathrm{l}$, when compared with HIV-negative VL patients [60]. The unfavorable outcomes of co-infected patients prompted the Brazilian Health Ministry to revise therapeutic guidelines in 2013 and recommended HIV co-infection as an indication for therapy with liposomal amphotericin, which is more expensive and has a reduced toxicity as well as a high level of efficacy with a $90 \%$ cure rate [61]. Overlapping HIV and HVL prevalence increases the risk of a HVL outbreak and possibly a drug-resistant one [62].

Concomitant HIV infection increases the risk of developing active HVL by between 100 and 230 times [63], and AIDS also disproportionately affects the Brazilian urban poor [64]. Coupled with the change in transmission HVL pattern from the countryside to cities, this has led to a surge of epidemic of L. infantum-HIV co-infections in urban areas [65]. A recent ecological study identified high-risk areas of human HVL cases, with most clinical cases being among children and as opportunistic infections in HIV-infected patients [66] in the northern part of Belo Horizonte, the capital of the state Minas Gerais. This high-risk area also had a higher prevalence of poverty and a higher number of infected dogs per inhabitants than other parts of the city [67]. Moreover, as parasitemia is frequent in HIV-HVL [68], co-infected patients may be highly infectious to phlebotomine sandflies [69], leading to increased HVL within the community. 


\section{Surveillance and control strategies}

The Brazilian National System for Surveillance and Control of Diseases is a decentralized, hierarchical, and integrated network that uses a horizontal approach, which attempts to reduce other vector-borne diseases along with a broad-based participatory approach, as part of the Unified Health System [70]. The backbone of the national HVL Control and Surveillance Program is to reduce the morbidity and case fatality rates through early diagnosis and treatment of human cases. Moreover, it sets to curb the transmission risk by means of controlling the population of both domestic reservoirs and the vector [71]. The program coordinates (i) vector population control by means of residual insecticide spraying and environmental management and (ii) culling of seropositive dogs in areas with moderate to high levels of transmission [72]. This approach lies upon the assumption that the incidence of $L$. infantum infection in humans is directly related to the number of infectious dogs and the vector capacity of the sandfly population to transmit infection from dogs to humans [73]. Epidemiological surveillance of HVL, insecticide spraying, and dog culling control activities have been decentralized to municipalities, which since 1994, have been given responsibility to plan and provide these services [74].

\section{Program limitations}

The decentralization program was initially successful in putting in place a large-scale deployment of insecticide spraying and dog culling [75]. However, the spread of HVL to urban settings after more than 40 years of largescale deployment of insecticide spraying and dog culling prompts an urgent revision of the Brazilian HVL control program [76], since both strategies have obtained limited results in interrupting transmission [61, 76, 77]. Since the mid-eighties, studies have reported HVL in large urban centers, including the southeastern metropolitan areas of São Paulo [78], Rio de Janeiro [79], and Belo Horizonte $[80,81]$ as well as in the northeastern capitals of Teresina [74], São Luis [82, 83], and Fortaleza [84]. A systematic review of studies conducted in Latin America underscores the lack of scientific evidence to support the effectiveness of such interventions [85], and also highlights the need to address the lack of political commitment, gaps in scientific knowledge, and poor case management and surveillance systems [77].

The decentralization of epidemiological surveillance and HVL control activities to the municipalities has highlighted deficiencies in infrastructure at the local level for addressing the complexity of HVL control [86]. A recent non-significant effect of insecticide spraying on the incidence of human infection was determined for a community randomized controlled trial in Teresina, the capital of the Brazilian state of Piauí, in northeast Brazil.
It illustrated how the shortage of available equipment and trained personnel for large-scale spraying interventions hampers the sustainability of control actions [69, 84, 87-90].

Although dog culling appears to have been effective in reducing infection among humans in China [91], in Brazil, where infectious dogs have been estimated to have an $R_{0}$ of approximately 6 [92], HVL has surged in the past two decades despite the spraying of 200,000 houses and killing of 20,000 seropositive dogs per year [93]. A mathematical model estimated that killing two thirds of the infected dog population would result in less than $20 \%$ reduction in the incidence of human disease [94]. Furthermore, immunofluorescence (IFI) antibody tests commonly used for mass screening of dogs [95] has low sensitivity and specificity [96], with estimates for sensitivity ranging from 72 to $100 \%$ and for specificity from 52 to $100 \%$ [84]. However, newer sensitive molecular diagnostic methods for canine visceral leishmaniasis, like the conjunctival swab (CS) real-time PCR reported that among the 1350 dogs screened, 369 (27.3\%) were positive by CS real-time PCR and 126 (9.3\%) tested positive by serological assays, which demonstrate its potential as a mass screening tools in endemic settings to contribute to disease control [97].

A recent simulation study in Brazil indicated that very low transmission settings (3\% prevalence), culling of only symptomatic dogs, is sufficient to maintain prevalence under $1 \%$. In higher endemicity settings $\left(R_{0}=1.29\right.$, prevalence $\left.=15 \%\right)$ [98], removing clinically diagnosed dogs, would be insufficient as a control strategy given that the asymptomatic population of dogs would be significant enough to maintain transmission [75, 87, 99-101].

The failure of dog culling to reduce human cases may also suggest the possibility of other reservoirs [102]. A recent serological survey performed in Petrolina showed that cats had a prevalence of $3.9 \%$ of HVL [103].

Studies have shown that humans, crab-eating foxes, opossums, domestic cats, and black rats can also transmit L. infantum to sandflies; nevertheless, their importance is deemed to be minimal [77]. However, in certain scenarios these secondary reservoirs would be capable of sustaining transmission, which would warrant further studies on their transmission potential [104].

\section{HVL clinical management within a decentralized context}

The decentralization of health care to the municipality level also has had an impact on the early detection and effective clinical management of HVL. A study in northwestern Paraná State revealed that both early treatment initiation and clinical evaluation were more complete with a centralized healthcare system than with a decentralized one [105]. After the decentralization, $32 \%$ of 
patients were treated with the first line drug, pentavalent antimonial, and were treated without compliance to the recommended dosage of 30 days at $20 \mathrm{mg} / \mathrm{kg} /$ day [106]. Furthermore, $73 \%$ of patients in the study were noted to having received inadequate treatment, and $84 \%$ of patients failed to receive proper clinical follow-up [106]. The lack of rigorous clinical management ensuing decentralization may have an even more profound effect for clinical management of co-infection HIV-HVL, in whom HVL appears in atypical forms and is more difficult to diagnose [107].

\section{Knowledge gaps}

\section{Active surveillance}

The cost effectiveness of implementing an active surveillance system to detect HVL cases in endemic urban areas needs to be evaluated. Active surveillance in urban areas would entail involving community health workers in active case finding in the community in order to detect those patients who may not seek treatment in health facilities so that a more prompt treatment is initiated; this could be done through the use of RDT. Active case finding would enable more accurate estimates of HVL in urban areas to allow a better understanding of the actual burden. Additionally, active case finding would provide the data needed to the reliable estimates of HIV-HVL co-infection, which is currently lacking in northeast Brazil. In 2012, HIV-HVL co-infection prevalence was $8.5 \%$ of all HVL cases [108]; however, there are likely a significant number of asymptomatic co-infected individuals which are undetected $[109,110]$. The use of different diagnostic tests for active surveillance should also be evaluated, to understand the health and cost implications of differing technologies.

\section{Identification of other potential reservoirs and transmission risk factors}

In zoonotic disease control, early diagnosis and treatment is essential for the patient, but is believed to have limited impact on transmission if the main animal reservoir or insect vectors are not targeted [111]. In Brazil, transmission risk factors for HVL are still insufficiently elucidated, notably in urban and densely populated areas [112]. The transmission potential by asymptomatic canine as well as the identification of other potential reservoirs needs to be determined. In the Indian continent, mathematical modeling has suggested that Leishmania donovani in asymptomatic individuals may also be an instrumental in maintaining transmission in endemic communities [113]. Mathematical modeling is also needed to determine whether L. infantum in asymptomatic individuals are also instrumental in maintaining transmission in endemic communities.

\section{Effectiveness of interventions}

A systematic review of studies conducted in Latin America underscores the lack of scientific evidence to support the effectiveness of such interventions [84], and also highlights the need to address the lack of political commitment, gaps in scientific knowledge, and poor case management and surveillance systems [72]. Regular monitoring of human, vector, and reservoir VL at municipality level is vital to guide and tailor the HVL control strategy in urban centers.

\section{Impact of the decentralization on HVL surveillance and control interventions}

There is limited research on the impact of decentralization on HVL surveillance, sandfly control, dog culling, culling of seropositive dogs, and case management. There should be a comprehensive review, which will identify the deficiencies in the system, such as bottlenecks in service provision or resources to appropriate implement a program.

\section{HIV-related gaps Clinical management of HIV-HVL co-infection in Brazil}

The recommendation to treat HIV-infected patients with amphotericin B was based on the opinion of experts and from clinical trials mostly conducted in India [114]. In East Africa, cure rates have had limited results, with $56 \%$ of VL relapse cases demonstrating parasitological failure in Northern Ethiopia [115], and in Mediterranean countries [116]. Its efficacy in Brazil has yet to be established, and this recommendation should be further examined in the Brazilian context.

\section{Impact of HAART on HVL clinical management}

HVL relapses have been shown to occur in patients on highly active antiretroviral therapy (HAART), despite increasing CD4+ counts and undetectable HIV loads [117, 118]. Moreover, HVL also seems to hamper the immunological recovery of the HIV-positive patients treated with HAART [119]. It remains to be investigated whether earlier CD4 count initiation may prevent HVL relapses.

\section{Impact of HAART on drug-resistant HVL}

In light of potential HIV-driven drug-resistant HVL outbreaks [120], the prevalence of drug-resistant HVL in $\mathrm{HIV}$-infected persons and immuno-epidemiological parameters should be determined. Moreover, the impact of earlier HAART initiation on preventing drug-resistant transmission should be HVL explored.

\section{Impact of HAART on the human reservoir}

HAART may also lead to asymptomatic carriers [121, 122 ] and these may pose a risk for transmission in areas 
where the sandfly vector is present [123]. Research will need to be conducted to assess how changes in the HAART landscape, such as the WHO 2013 recommendation to initiate treatment at CD4 >350 count [124], may contribute to maintaining transmission in endemic communities.

\section{Conclusions}

There is evidence that suggests the current practices of HVL control in Brazil have not been effective at controlling the spread of HVL. The lack of control effectiveness may be attributed to deficiencies in infrastructure at the local level for addressing the complexity of HVL control, in addition to the decentralization of health care to the municipality level, as well as clinical and epidemiological knowledge gaps.

Whilst decentralization of health care in Brazil has enhanced community participation [125], early diagnosis and treatment of human cases has also been impacted negatively by decentralization, with poor adherence of the standard treatment being reported in first-line treatment in resource-poor municipalities. Municipalities may lack the high level of clinical expertise to deal with the challenges that HIV-HVL co-infection management entail. These include suboptimal sensitivity of point of point-of-care diagnostics that require reliance on more invasive tests for monitoring lower cure rates, higher drug toxicity, drug interaction with HAART, relapse and mortality rates than those without HIV [126].

With cases of HIV-HVL co-infection burgeoning, the human transmission potential may be underestimated. As HIV disproportionately affects the Brazilian urban poor [127], who in turn are more at risk of living in poor municipalities and being co-infected with HVL, poor municipalities may fuel both a HIV-HVL epidemic and drug-resistant HVL transmission.

HVL should be considered as a disease with focal transmission [107], in which the conditions for transmission depend on local socio-economic factors. Despite the milestones in the HVL and in the canine HVL diagnostic landscape, which would enable rapid diagnoses at local level, a balance must be drawn between government and community involvement for control initiatives if local HVL control programs are to be sustained.

\section{Abbreviations \\ HAART: highly active antiretroviral therapy; HIV: human immunodeficiency virus; HVL: human visceral leishmaniasis.}

\section{Competing interests}

The authors declare that they have no competing interests.

\section{Authors' contributions}

SM lead author identified the literature, interpreted the findings and drafted the manuscript. RR, LN, and $K Z$ participated in the interpretation of findings and in the revision of the article. All authors read and approved the final manuscript.

\section{Acknowledgement}

Dr Britt McKinnnon and Clarice Hofbeck were involved in revising the manuscript.

\section{Author details \\ ${ }^{1}$ International Centre for Reproductive Health (ICRH), Ghent University, De Pintelaan 185 P3, 9000 Ghent, Belgium. '²epartment of Epidemiology and Biostatistics, McGill University, Montreal, Canada. ' ${ }^{3}$ SSHTM alumni, Beirut, Lebanon. ${ }^{4}$ Department of Social and Preventive Medicine, Laval University, Boston, USA. ${ }^{5}$ Boston Children's Hospital, Harvard Medical School, Boston, MA, USA.}

Received: 10 December 2015 Accepted: 17 March 2016

Published online: 21 April 2016

\section{References}

1. Alvar J, Aparicio P, Aseffa A, DenBoer M, Cañavate C, Dedet JP, et al. The relationship between leishmaniasis and AIDS: the second 10 years. Clin Micro Biol Rev. 2008;21:334-59.

2. David L. Heymann. Control of Communicable Diseases Manual, 19th edition American Public health association and WHO. 2008.

3. Alvar J, Cañavate C, Molina R, Moreno J, Nieto J. Canine leishmaniasis. Adv Parasitol. 2004;57:1-88

4. Ribas LM, Zaher VL, Shimozako HJ, Massad E. Estimating the optimal control of zoonotic visceral leishmaniasis by the use of a mathematical model. Sci World J. 2013. 81038010.1155/2013/810380.

5. Bern C, Maguire JH, Alvar J. Complexities of assessing the disease burden attributable to leishmaniasis. PLoS Negl Trop Dis. 2008;2:e313.

6. Ministry of Health of Brazil. Casos confirmados de leishmaniose visceral, segundo UF de residência, Brasil, grandes regiões e unidades federadas. 1990 a 2006. 2008. http://u.saude.gov.br/images/pdf/2014/setembro/09/LVCasos.pdf Available from: (Accessed 10 Dec 2008).

7. Werneck GL, Rodrigues L, Santos MV, Araujo IB, Moura LS, et al. The burden of Leishmania chagasi infection during an urban outbreak of visceral leishmaniasis in Brazil. Acta Trop. 2002;83:13-8.

8. Harhay MO, Olliaro PL, Costa DC, Costa CHN. Urban parasitology: visceral leishmaniasis in Brazil. Trends Parasitol. 2011;27:403-9.

9. Werneck GL. Expansão geográfica da leishmaniose visceral no Brasil. Cad Saude Publica. 2010;26(4):644-5.

10. Barreto ML, Teixeira MG, Bastos Fl, Ximenes RAA, Barata RB, Rodrigues LC. Sucessos e fracassos no controle de doenças infecciosa no Brasil: o contexto social e ambiental, políticas, intervenções e necessidades de pesquisa. Lancet. 2011;3:47-60.

11. Murray HW, Berman JD, Davies CR, Saravia NG. Advances in leishmaniasis. Lancet. 2005:366:1561-77.

12. Mondain-Miton V, Toussaint-Gari M, Hofman P, Marty P, Carles M, et al. Atypical leishmaniasis in a patient infected with human immunodeficiency virus. Clin Infect Dis. 1995;21:663-5.

13. Romeu J, Milla F, Batlle M, Sirera G, Ferrandiz C, et al. Visceral leishmaniasis involving lung and a cutaneous Kaposi's sarcoma lesion. AIDS. 1991;5:1272.

14. Lopez-Velez R, Perez-Molina JA, Guerrero A, Baquero F, Villarrubia J, et al. Clinicoepidemiologic characteristics, prognostic factors, and survival analysis of patients coinfected with human immunodeficiency virus and Leishmania in an area of Madrid, Spain. Am J Trop Med Hyg. 1998;58:436-43.

15. de Valliere S, Mary C, Joneberg JE, Rotman S, Bullani R, et al. AA-amyloidosis caused by visceral leishmaniasis in a human immunodeficiency virusinfected patient. Am J Trop Med Hyg. 2009;81:209-12.

16. Preiser W, Cacopardo B, Nigro L, Braner J, Nunnari A, Doerr HW, et al. Immunological findings in HIV-Leishmania coinfection. Intervirology. 1996:39:285-8.

17. Hurissa Z, Gebre-Silassie S, Hailu W, Tefera T, Lalloo DG, Cuevas LE, et al. Clinical characteristics and treatment outcome of patients with visceral leishmaniasis and HIV coinfection in northwest Ethiopia. Trop Med Int Health. 2010;15:848-55.

18. Sousa-Gomes ML, Maia-Elkhoury ANS, Pelissari DM, Lima Junior FEF, Sena $J M$, et al. Co-infection leishmania/HIV in Brazil: epidemiological, clinical and laboratorial aspects]. Epidemiol Serv Saude. 2011;20:519-26.

19. Daher EF, Fonseca PP, Gerhard ES, Leitão TM, Silva Júnior GB. Clinical and epidemiological features of visceral leishmaniasis and HIV coinfection in fifteen patients from Brazil. J Parasitol. 2009;95:652-5. 
20. Guanais FC, Macinko J. The health effects of decentralizing primary care in Brazil. Heal Aff. 2009;28(4):1127-35.

21. Lacerda M. The Brazilian leishmaniasis control program. Mem Inst Oswaldo Cruz. 1994;89:489-95.

22. Furtado VJB, Coelho EG. Leishmaniose visceral ou calazar: aspectos epidemiológicos e de controle. Rev Soc Bras Med Trop. 1998;31:85-92.

23. Tauil PL. Perspectives of vector borne diseases control in Brazil. Rev Soc Bras Med Trop. 2006;39(3):275-7.

24. Paim J, Travassos C, Almeida C, Bahia L, Macinko J. The Brazilian health system: history, advances, and challenges. Lancet. 2011;377(9779):1778-97.

25. Khanal B, Picado A, Bhattarai NR, Van Der Auwera G, Das ML, Ostyn B, et al. Spatial analysis of Leishmania donovani exposure in humans and domestic animals in a recent kala azar focus in Nepal. Parasitol. 2010;137:1597-603.

26. Dantas-Torres F, Almeida FA, Brandão-Filho SP. Phlebotomine sandflies of an urban focus of visceral leishmaniosis, Pernambuco State. Rev Patol Trop. 2006;34:157-60.

27. Quinnell RJ, Courtenay O, Garcez L, Dye C. The epidemiology of canine leishmaniasis: transmission rates estimated from a cohort study in Amazonian Brazil. Parasitology. 1997;115(Pt 2):143-56. doi:10.1017/ S0031182097001200.

28. Pimentel Dde $\mathrm{S}$, et al. Prevalence of zoonotic visceral leishmaniasis in dogs in an endemic area of Brazil. Rev Soc Bras Med Trop. ahead of print Epub June 26, 2015

29. Amóra SSA, Bevilaqua CML, Feijó FMC, Alves ND, Maciel MV. Control of phlebotomine (Diptera: Psychodi dae) leishmaniasis vectors. Neotrop Entomol. 2009;38:303-10

30. Marcondes C. Visceral leishmaniasis control in Brazil: time to re-evaluate DDT? Terrestrial Arthropod Rev. 2014;7:21-39. doi:10.1163/1874983600001072.

31. de Almeida AS, Medronho Rde A, Werneck GL. Identification of risk areas for visceral leishmaniasis in Teresina, Piaui State, Brazil. Am J Trop Med Hyg. 2011;84:681-7.

32. Ministry of Health of Brazil. Casos confirmados de Leishmaniose Visceral, Brasil, Grandes Regiões e Unidades Federadas. 1990 a 2009. 2010. Available: http://dtr2004.saude.gov.br/sinanweb/tabnet/dh?sinannet/leishvi/bases/ leishvbrnet.def. Accessed 10 Dec 2015.

33. Ministry of Health of Brazil. Letalidade por Leishmaniose Visceral. Brasil, Grandes Regiões e Unidades Federadas, 2000 a 2009. 2010. Available: http://www.ncbi.nlm.nih.gov/pmc/articles/PMC3274500/. Accessed 10 Dec 2015.

34. Elkhoury M, Silveira AN, et al. Visceral leishmaniasis in Brazil: trends and challenges. Cad Saúde Pública. 2008;24(12):2941-7.

35. Romero GA, Boelaert M. Control of visceral leishmaniasis in Latin America: a systematic review. PLoS Negl Trop Dis. 2010;4:e584.

36. Furtado AS, Nunes FB, Santos AM, Caldas AJ. Space-time analysis of visceral leishmaniasis in the State of Maranhão, Brazil. Ciên Saúde Colet. 2015;20(12):3935-42

37. Nascimento ET, Moura ML, Queiroz JW, Barroso AW, Araujo AF, et al. The emergence of concurrent HIV-1/AIDS and visceral leishmaniasis in Northeast Brazil. Trans R Soc Trop Med Hyg. 2011;105:298-300. doi:10.1016/j.trstmh. 2011.01.006

38. Albuquerque LC, Mendonça IR, Cardoso PN, Baldaçara LR, Borges MR, Borges Jda C, et al. HIV/AIDS-related visceral leishmaniasis: a clinical and epidemiological description of visceral leishmaniasis in northern Brazil. Rev Soc Bras Med Trop. 2014:47(1):38-46.

39. Rabello A, Orsini M, Disch J. Leishmania/HIV co-infection in Brazil: an appraisal. Ann Trop Med Parasitol. 2003;97(1):17-28.

40. Orsini M, Canela JR, Disch J, et al. High frequency of asymptomatic Leishmania spp. infection among HIV-infected patients living in endemic areas for visceral leishmaniasis in Brazil. Trans R Soc Trop Med Hyg. 2012;106:283-8.

41. Ministério da Saúde. Secretaria de Vigilância em Saúde. Leishmaniose Visceral - Recomendações para Redução da Letalidade. Brasília; 2011. http:// sbmt.org.br/portal/wp-content/uploads/2013/01/lv_reducao_letalidade_ web.pdf. Accessed 6 Feb 2016.

42. Ministério da Saúde. Secretaria de Vigilância em Saúde. Manual de Vigilância e Controle da Leishmaniose Visceral. Brasília; 2006. 120 p http://bvsms. saude.gov.br/bvs/publicacoes/manual_vigilancia_controle_leishmaniose_ visceral.pdf. Accessed 6 Feb 2016

43. Moura AS, Lopes HW, Mourão MV, Morais MH. Performance of a rapid diagnostic test for the detection of visceral leishmaniasis in a large urban setting. Rev Soc Bras Trop. 2013;46:589-93.
44. Assis TSM, Braga ASC, Pedras MJ, Oliveira E, Barral A, Siqueira IC, et al. Multi-centric prospective evaluation of rk39 rapid test and direct agglutination test for the diagnosis of visceral leishmaniasis in Brazil. Trans R Soc Trop Med Hyg. 2011;105:81-5.

45. Schallig HDFH, Canto-Cavalheiro M, Silva ES. Evaluation of the direct agglutination test and the rK39 dipstick test for the sero-diagnosis of visceral leishmaniasis. Mem Inst Oswaldo Cruz. 2002;97:1015-8.

46. Carvalho SFG, Lemos EM, Corey R, Dietze R. Performance of recombinant $\mathrm{K} 39$ antigen in the diagnosis of Brazilian visceral leishmaniasis. Am J Trop Med Hyg. 2003;68:321-4

47. Amato Neto V, Amato VS, Tuon FF, Gakiya E, Marchi CR, Souza RM, et al. False-positive results of a rapid K39-based strip test and Chagas disease. Int Infet Dis. 2009;13:182-5.

48. Moura AS, Lopes HW, Mourão MV, Morais MH. Performance of a rapid diagnostic test for the detection of visceral leishmaniasis in a large urban setting. Rev Soc Bras Trop. 2013;46:589-93.

49. Diro E, Hurissa Z, van Griensven J, Hailu A. Unusual presentations of visceral leishmania in the era of HIV. In: Proceedings of the 16th International Conference on AIDS and STIs in Africa (ICASA). Addis Ababa, Ethiopia; 2011.

50. Gao C, Yang Y, Shi F, Wang J, Steverding D, Wang X. Development of an immunochromatographic test for diagnosis of visceral leishmaniasis based on detection of a circulating antigen. Schallig HDFH, ed. PLoS Negl Trop Dis. 2015;9(6):e0003902. doi:10.1371/journal.pntd.0003902.

51. Grogl M, Thomason TN, Franke ED. Drug resistance in leishmaniasis: its implication in systemic chemotherapy of cutaneous and mucocutaneous disease. Am J Trop Med Hyg. 1992;47:117-26.

52. Marsden PD. Mucosal leishmaniasis due to Leishmania (Viannia) braziliensis L(V)b in Três Braços, Bahia, Brazil. Rev Soc Bras Med Trop. 1994;27:93-101.

53. Netto EM, Marsden PD, Llanos-Cuentas EA, Costa JML, Cuba CC, Barreto AC, et al. Long-term follow-up of patients with Leishmania (Viannia) brasiliensis infection and treated with Glucantime ${ }^{\oplus}$. Trans R Soc Trop Med Hyg. 1990;84:367-70.

54. Sampaio RNR, Sampaio JHD, Marsden PD. Pentavalent antimonial treatment in mucosal leishmaniasis. Lancet. 1985;1:1097.

55. Alvar J, Aparicio P, Aseffa A, DenBoer M, Cañavate C, Dedet JP, et al. The relationship between leishmaniasis and AIDS: the second 10 years. Clin Micro Biol Rev. 2008:21:334-59.

56. Cota GF, de Sousa MR, Rabello A. Predictors of visceral leishmaniasis relapse in HIV-infected patients: a systematic review. PLoS Negl Trop Dis. 2011:5:e1153.

57. Bentwich Z. Concurrent Infections that rise the HIV viral load. J HIV Ther. 2003;8:72-5.

58. Cacopardo B, Nigro L, Preiser FA, Satariano MI, Braner J, et al. Prolonged Th2 cell activation and increased viral replication in HIV-Leishmania coinfected patients despite treatment. Transactions Trans R Soc Trop Med Hyg. 1996;90:434-5.

59. Pintado V, Lopez-Velez R. HIV-associated visceral leishmaniasis. Clin Microbiol Infect. 2001:7:291-300.

60. Monge-Maillo B, Norman FF, Cruz I, Alvar J, López-Vélez R. Visceral Leishmaniasis and HIV coinfection in the Mediterranean Region. PLoS Negl Trop Dis. 2014;8(8):e3021. doi:10.1371/journal.pntd.0003021.

61. Murray HW. Progress in the treatment of a neglected infectious disease: visceral leishmaniasis. Expert Rev Anti Infect Ther. 2004;2(2):279-92.

62. Bryceson AD, Chulay JD, Ho M, Mugambii M, Were JB, Muigai R, et al. Visceral leishmaniasis unresponsive to antimonial drugs. 1. Clinical and immunological studies. Trans R Soc Trop Med Hyg. 1985;79:700-4.

63. WHO 2015 Visceral Leishmaniasis, Accessed 5 Sept 2015.

64. Muñoz-Laboy MA, Murray L, [...], Parker RG. Beyond faith-based organizations: using comparative institutional ethnography to understand religious responses to HIV and AIDS in Brazil. Am J Public Health. 2011; 101(6): 972-978.

65. Maia-Elkhoury ANS, Alves WA, Sousa-Gomes ML, Sena JM, Luna EA. Visceral leishmaniasis in Brazil: trends and challenges. Cad Saude Publica. 2008;24:2941-7.

66. Podaliri Vulpiani M, lannetti L. Methods of control of the leishmania infantum dog reservoir: state of the art. Vet Med Int. 2010;2011(2011):13. doi:10.4061/2011/215964.

67. De Araújo VEM, Pinheiro LC, Almeida MC de M, et al. Relative risk of visceral leishmaniasis in Brazil: a spatial analysis in urban area. Kamhawi S, ed. PLoS Negl Trop Dis. 2013;7(11):e2540. doi:10.1371/journal.pntd.0002540.

68. Harms G, Feldmeier H. HIV infection and tropical parasitic diseases - deleterious interactions in both directions. Trop Med Int Health. 2002;7:4770-88.

69. Molina R, Lohse JM, Pulido F, et al. Infection of sand flies by humans coinfected with Leishmania infantum and human immunodeficiency virus. Amer J Trop Med Hyg. 1999;60:51-3. 
70. Barreto ML, Teixeira MG, Bastos Fl, Ximenes RA, Barata RB, et al. Successes and failures in the control of infectious diseases in Brazil: social and environmental context, policies, interventions, and research needs. Lancet. 2011;377:1877-1889. doi: http://dx.doi.org/10.1016/S0140-6736(11)60202-X.

71. Araujo VEM, Pinheiro LC, Mattos Almeida MC, Menezes FC, Morais MHF, Reis IA, et al. Relative risk of visceral leishmaniasis in Brazil: a spatial analysis in urban area. PLoS Negl Trop Dis. 2013;7:e2540.

72. Brasil. Ministério da Saúde SdVeSDdVE. Manual de vigilância e controle da leishmaniose visceral. Brasília: Ministério da Saúde; 2006. p. 120.

73. Dye C. The logic of visceral leishmaniasis control. Am J Trop Med Hyg. 1996;55:125-30.

74. Ruffino-Netto A et al. Rev Panam Salud Publica vol.9 n.5 Washington, US. 2001. http://dx.doi.org/10.1590/S1020-49892001000500004.

75. Werneck GL, Costa CHN, et al. Effectiveness of insecticide spraying and culling of dogs on the incidence of Leishmania infantum infection in humans: a cluster randomized trial in Teresina, Brazil. PLoS Negl Dis. 2014. doi:10.1371/journal.pntd.0003172.

76. Costa $\mathrm{CH}$. How effective is dog culling in controlling zoonotic visceral leishmaniasis? A critical evaluation of the science, politics and ethics behind this public health policy. Rev Soc Bras Med Trop. 2011;44:232-42. doi:10. 1590/s0037-86822011005000014.

77. Quinnell RJ, Courtenay O. Transmission, reservoir hosts and control of zoonotic visceral leishmaniasis. Parasitology. 2009;136:1915-34. doi:10.1017/ s0031182009991156

78. Iversson LB, Pires SRBR, Ribeiro MA. Investigação epidemiológica de um novo caso de leishmaniose visceral ocorrido na grande São Paulo, Brasil. Rev Saude Publica. 1882;16:205-19.

79. Marzochi MCA, Coutinho SG, De Souza WJ, De Toledo LM. Canine visceral leishmaniasis in Rio de Janeiro, Brazil: clinical, parasitological, therapeutical and epidemiological findings (1977-1983). Mem Inst Oswaldo Cruz. 1985;80:349-57.

80. Oliveira $\mathrm{CL}$, Assunção RM, Reis IA. Spacial distribution of human and canine visceral leishmaniasis in Belo Horizonte, Minas Gerais State, Brazil, 19941997. Cad Saude Publica. 2001;7:1231-9.

81. Silva ES, Gontijo CMF, Pacheco RS, Fiuza VOP, Brazil RP. Visceral leishmaniases in the metropolitan region of Belo Horizonte, State of Minas Gerais, Brazil. Mem Inst Oswaldo Cruz. 2001;93:285-91.

82. Costa $\mathrm{CH}$, Pereira HF, Araujo MV. Epidemia de leishmaniose visceral no Estado do Piauí, Brasil, 1980-1986. Rev Saude Publica. 1990;24:361-72.

83. Mendes WS, Da Silva AAM, Trovão JJ. Expansão espacial da leishmaniose visceral americana em São Luis, Maranhão, Brasil. Rev Soc Bras Med Trop. 2002:35:227-31.

84. Alves AL, Bevilaqua CML, Moraes NB, Franco SO. Levantamento epidemiológico da leishmaniose visceral em cães vadios da cidade de Fortaleza, Ceará. Ciência Anim. 1998;8:63-8.

85. Romero GA, Boelaert M. Control of visceral leishmaniasis in Latin America—a systematic review. PLoS Negl Trop Dis. 2010;4:e584. doi:10.1371/ journal.pntd.0000584.

86. Nascimento EL, Martins DR, et al. Forum: geographic spread and urbanization of visceral leishmaniasis in Brazil. Postscript: new challenges in the epidemiology of Leishmania chagasi infection. Cad Saúde Pública. 2008;24 (12): Rio de Janeiro.

87. Costa $\mathrm{CH}$, Tapety CM, Werneck GL. Controle da leishmaniose visceral em meio urbano: estudo de intervencao randomizado fatorial. Rev Soc Bras Med Trop. 2007:40:415-9. doi:10.1590/s0037-86822007000400009.

88. Dantas-Torres F, Brandao-Filho SP. Visceral leishmaniasis in Brazil: revisiting paradigms of epidemiology and control. Rev Inst Med Trop Sao Paulo. 2006:48:151-6. doi:10.1590/s0036-46652006000300007.

89. Desjeux P. Leishmaniasis: current situation and new perspectives. Comp Immunol Microbiol Infect Dis. 2004;27:305-18. doi:10.1016/j.cimid.2004.03.004

90. Alexander B, Maroli M. Control of phlebotomine sandflies. Med Vet Entomol. 2003;17:1-18. doi:10.1046/j.1365-2915.2003.00420.x.

91. Gavgani AS, Hodjati MH. Effect of insecticide-impregnated dog collars on incidence of zoonotic visceral leishmaniasis in Iranian children: a matched cluster randomised trial. Lancet. 2002;360(Issue 9330):374-379.

92. Quinnell RJ, Courtenay O, Garcez L, Dye C. The epidemiology of canine leishmaniasis: transmission rates estimated from a cohort study in Amazonian Brazil. Parasitology. 1997;115(Pt 2):143-56. doi:10.1017/ S0031182097001200.

93. Proceeding of the Second International Canine Leishmaniasis Conference. Canine Leishmaniasis, moving towards a solution. 2002. http://www.
studioveterinariosanrocco.it/Atti\%202nd\%20Int\%20CanL\%20Forum\% 20Siviglia\%202002.pdf. Accessed 25 Jan 2016.

94. Dye C. The logic of visceral leishmaniasis control. Am J Trop Med Hyg 1996;55:125-30

95. Passantino A. Medico-legal considerations of canine leishmaniosis in Italy: an overview of an emerging disease with reference to the buying and selling of dogs. Rev Sci Tech. 2006;25(3):1111-23.

96. Reithinger R, Quinnell RJ, Alexander B, Davies CR. Rapid detection of Leishmania infantum infection in dogs: comparative study using an immunochromatographic dipstick test, enzyme-linked immunosorbent assay, and PCR. J Clin Microbiol. 2002;40:2352-6.

97. Leite RS, Souza NA, Barbosa AD. Evaluation of conjunctival swab as a massscreening tool for molecular diagnosis of canine visceral leishmaniasis. Parasitol Res. 2015;114(6):2255-62. doi:10.1007/s00436-015-4418-y.

98. Costa DNCC, Codeço CT, Silva MA, Werneck GL. Culling dogs in scenarios of imperfect control: realistic impact on the prevalence of canine visceral leishmaniasis. Ghedin E, ed. PLoS Negl Trop Dis. 2013;7(8):e2355. doi:10.1371/journal.pntd.0002355.

99. Ferroglio E, Centarob E, Mignonec W, Trisciuoglioa A. Evaluation of an ELISA rapid device for the serological diagnosis of Leishmania infantum infection in dog as compared with immunofluorescence assay and western blot. Vet Paras. 2007;144:162-6. doi:10.1016/j.vetpar.2006.09.017.

100. Courtenay O, Quinnell RJ, Garcez LM, Shaw JJ, Dye C. Infectiousness in a cohort of Brazilian dogs: why culling fails to control visceral leishmaniasis in areas of high transmission. Med Vet Ent. 2002;186:1314-20. doi:10.1086/344312.

101. Molina R, Lohse JM, Pulido F, Laguina F, López-Vélez R, et al. Infection of sand flies by humans coinfected with Leishmania infantum and human immunodeficiency virus. Am J Trop Med Hyg. 1999;60(1):51-3.

102. Vulpiani MP, lannetti L, Paganico D, lannino F, Ferri N. Methods of control of the Leishmania infantum dog reservoir: state of the art. Vet Med Internatl. 2011;2011:215964

103. Silva RCN, Ramos RAN, Pimentel DS, Oliveira GMA, Carvalho GA, Santana MA et al. Detection of antibodies against Leishmania infantum in cats (Felis catus) from the State of Pernambuco, Brazil. Rev Soc Bras Med Trop. 2014;47:108-9.

104. Werneck GL, Costa CH, et al. Effectiveness of insecticide spraying and culling of dogs on the incidence of Leishmania infantum infection in humans: a cluster randomized trial in Teresina, Brazil. PLoS Negl Trop Dis. 2014. doi:10.1371/journal.pntd.0003172.

105. de Lima MV, Oliveira RZ, et al. Treatment of patients with American cutaneous leishmaniasis: health services evaluation in northwestern Paraná State, Brazil. Cad Saude Publica. 2007;23(12):2938-48.

106. Freitas-Junior LH, Chatelain E, Kim HA, Siqueira-Neto JL. Visceral leishmaniasis treatment: what do we have, what do we need and how to deliver it? Int J Parasitol. 2012;2:11-9. doi:10.1016/j.ijpddr.2012.01.003.

107. Sinha PK, Pandey K, Bhattacharya SK. Diagnosis \& management of leishmania/HIV co-infection. Indian J Med Res. 2005;121:407-14.

108. Lindoso JA, Cota GF, da Cruz AM, Goto H, Maia-Elkhoury AN, et al. Visceral leishmaniasis and HIV coinfection in Latin America. PLoS Negl Trop Dis. 2014; 18; 8 (9): e3136. doi:10.1371/journal.pntd.0003136.

109. de Gouvea-Vianna L, de Assis TS, Orsini M, da Silva AR, de Souza GF, et al. Combined diagnostic methods identify a remarkable proportion of asymptomatic Leishmania (Leishmania) chagasi carriers who present modulated cytokine profiles. Trans R Soc Trop Med Hyg. 2008;102:548-55.

110. Carranza-Tamayo CO, de Assis TS, Neri AT, Cupolillo E, Rabello A, et al, Prevalence of Leishmania infection in adult HIV/AIDS patients treated in a tertiary-level care center in Brasilia, Federal District, Brazil. Trans R Soc Trop Med Hyg. 2009;103:743-8.

111. Dye C. The logic of visceral leishmaniasis control. Am J Trop Med Hyg. 1996:55:125-30

112. De Araújo VEM, Pinheiro LC, Almeida MC de M, et al. Relative risk of visceral leishmaniasis in Brazil: a spatial analysis in urban area. Kamhawi S, ed. PLoS Negl Trop Dis. 2013;7(11):e2540. doi:10.1371/journal.pntd.0002540.

113. Stauch A, Sarkar RR, Picado A, Ostyn B, Sundar S, et al. Visceral leishmaniasis in the Indian subcontinent: modelling epidemiology and control. PLoS Negl Trop Dis. 2011:5:e1405. doi:10.1371/journal.pntd.0001405.

114. Olliaro PL, Guerin PJ, Gerstl S, Haaskjold AA, Rottingen JA, Sundar S. Treatment options for visceral leishmaniasis: a systematic review of clinical studies done in India, 1980-2004. Lancet Infect Dis. 2005;5(12):763-74.

115. Ritmeijer $\mathrm{K}$, ter Horst $\mathrm{R}$, Chane S, Aderie EM, Piening T, et al. Limited effectiveness of high-dose liposomal amphotericin B (AmBisome) for 
treatment of visceral leishmaniasis in an Ethiopian population with high HIV prevalence. Clin Infect Dis. 2011; 53: e152-e158.

116. Monge-Maillo B, Norman FF, Cruz I, Alvar J, López-Vélez R. Visceral leishmaniasis and HIV coinfection in the Mediterranean Region. PLoS Negl Trop Dis. 2014;8(8):e3021. doi:10.1371/journal.pntd.0003021.

117. Alvar J, Aparicio P, Aseffa A, Den Boer M, Cañavate C, et al. The relationship between leishmaniasis and AIDS: the second 10 years. Clin Microbiol Rev. 2008;21:334-59.

118. Gil-Prieto R, Walter S, Alvar J, de Miguel AG. Epidemiology of leishmaniasis in Spain based on hospitalization records (1997-2008). Am J Trop Med Hyg. 2011:85:820-5.

119. Lopez-Velez R. The impact of highly active antiretroviral therapy (HAART) on visceral leishmaniasis in Spanish patients who are co-infected with HIV. Ann Trop Med Parasitol. 2003;97 Suppl 1:143-7.

120. Pintado V, Lopez-Velez R. HIV-associated visceral leishmaniasis. Clin Microbiol Infect. 2001;7:291-300.

121. Bourgeois N, Bastien P, Reynes J, Makinson A, Rouanet I, et al. 'Active chronic visceral leishmaniasis' in HIV-1-infected patients demonstrated by biological and clinical long-term follow-up of 10 patients. HIV Med. 2002;11: 1010;670-673.

122. Colomba C, Saporito L, Vitale F, Reale S, Vitale G, et al. Cryptic Leishmania infantum infection in Italian HIV infected patients. BMC Infect Dis. 2009;9:199.

123. Molina I, Fisa R, Riera C, Falco V, Elizalde A, et al. Ultrasensitive real-time PCR for the clinical management of visceral leishmaniasis in HIV-infected patients. Am J Trop Med Hyg. 2013;89:105-10.

124. WHO. Consolidated guidelines on the use of antiretroviral drugs for treating and preventing HIV infection, recommendations for public health approach. 2013. http://www.who.int/hiv/pub/guidelines/arv2013/en/. Accessed 1 Feb 2016.

125. Bulletin of the World health organization Flawed but fair: Brazil's health system reaches out to the poor. http://www.who.int/bulletin/volumes/86/4/ 08-030408/en/. Accessed 1 Feb 2016.

126. de Melo EC, Fortaleza CM. Challenges in the therapy of visceral leishmaniasis in Brazil: a public health perspective. J Trop Med. 2013;2013:5.

127. Muñoz-Laboy M, Murray L, Wittlin N, Parker R. Beyond faith-based organizations: using comparative institutional ethnography to understand religious responses to HIV and AIDS in Brazil. Am J Public Health. 2011; 101(6):972-8. doi:10.2105/AJPH.2010.300081.

\section{Submit your next manuscript to BioMed Central and we will help you at every step:}

- We accept pre-submission inquiries

- Our selector tool helps you to find the most relevant journal

- We provide round the clock customer support

- Convenient online submission

- Thorough peer review

- Inclusion in PubMed and all major indexing services

- Maximum visibility for your research

Submit your manuscript at www.biomedcentral.com/submit 